\title{
Assessment of Tourism Suitability in Natural Tourism Object of Lengkuas Island, Sijuk District, Belitung Regency, Bangka Belitung Province
}

\author{
Reszi Ariefianda ${ }^{1, *}$, Jafron Wasiq Hidayat $^{1}$, and Eng Maryono ${ }^{1}$ \\ ${ }^{1}$ Master Program of Environmental Science, School of Postgraduate Studies, Diponegoro University, Semarang - Indonesia
}

\begin{abstract}
The emergence of the tourism era 4.0 is the impact of the 4.0 industrial revolution in the tourism sector. This era was marked by the ease of access to information through digital media. Marine Ecotourism is a tourism activity that reflects cultural heritage, participation, and welfare of local residents also efforts to conserve natural and environmental resources, especially in coastal and island areas. This study aims to determine the suitability of the Lengkuas Island tourist area and the strategy of management and development of Lengkuas Island object. This research was conducted in February - April 2019 on Lengkuas Island, Sijuk District, Belitung Regency, Bangka Belitung Province. Travel suitability measurements based on parameters in the specified matrix will then be adjusted to the Tourism Suitability Index. Variables that will be used consist of, water depth, beach type, beach brightness, beach width, beach slope, current velocity, land cover, dangerous biota, water base material, clean water availability. The results show that Stations 1 (97.6\%), II (94\%), and III (94\%) are very suitable for the category of recreation and swimming. Stations IV (19), V (19), And VI (19) are very suitable for tourist activities especially boating, banana boating, canoeing, and jet skiing.
\end{abstract}

Keywords: Lengkuas Island; Marine Tourism; Suitability Tourism.

\section{Introduction}

The tourism sector is enabled to contribute significantly to the economy of Indonesia. The number of tourists visiting small island destinations in Indonesia continues to increase from year to year, it is very necessary for government steps to manage and interpret policies for tourist areas. [1] Many researchers are concerned about the difficulty of making real improvements to the environment. Tourism is expected, an important role in the development of various cultures, environmental conservation and maintaining social relations. Increasing the role of tourism can be characterized by various things, including the increasingly affordable cost of travel with low-cost airlines, rules that facilitate foreign tourist traffic, the rise of arts and cultural festivals, improvements in transportation facilities and road infrastructure, and the stretching of the supporting sector tourism such as hotels and restaurants.

Tourism is one of the government's mainstay sectors to gain foreign exchange profits. Tourism is included in the top 4 contributors to Indonesia's foreign exchange after oil and gas were first, followed by coal, then palm oil.

The main strength of the Indonesian tourism industry is still natural resources and rich diversity of cultures, and relatively inexpensive costs. Some sectors related to the potential to hinder the industries that are still in the process of reform, for example about hygiene and health. The role of tourism in national development, besides being a source of foreign exchange earnings, also provides many benefits to other fields, including such as creating and expanding employment/business creation, increasing the income of the community and government, and encouraging environmental conservation. In era 4.0, must improve the business environment and increase investment in the tourism sector, increase digitalization and use of online marketing and distribution tools in the industry to meet new trends and consumer expectations, improve the skills and competencies of the tourism sector to improve career prospects and support the industry to find and maintain professionals with the right skills, and the last increase a tourist destination with the aim of complementing promotional efforts at national and regional [2]. Tourism contributes to production activities and national income, private sector growth and infrastructure development. Belitung Regency is an archipelago that has regional tourism resources which consist of natural tourist attractions, culture and special interests that are potential to be developed into the Tourism Industry. The tourism potential in Belitung Regency, Sijuk Sub-district includes Tanjung Kelayang Beach, Tanjung Tinggi Beach, Tanjung Binga Fisherman Village, Bird Island, Island of Sand and Lengkuas Island [3].

\footnotetext{
${ }^{*}$ Corresponding author: Reszi39@gmail.com
} 
The number of tourists continued to increase since 2014-2018 from 199,823 to 467,571 total visitors, in 2014 had a total visitors of 199,823 , then in 2015 had a total visitors of 251,440 , in 2016 had a total visitors of 292,885 , in 2017 had a total of 380,941 visitors and continued to increase in 2018 with a total of 467,571 visitors. Lengkuas Island Nature Tourism Objects are managed with the aim of providing benefits as a place to enjoy the beauty of nature and its ecosystem without damaging its natural sustainability and providing economic benefits to local residents.

The development of the tourist attraction of Lengkuas Island, Belitung Regency begins with identifying potential that can be developed, the area of Natural Tourism Objects includes the beauty of the beach, natural comfort, water recreation, snorkeling, diving and canoeing which are very rich in natural marine ecosystems and artificial recreation for children. Tourism development includes the establishment of tourism designated areas in accordance with the criteria of developing and synergizing tourism activities with limited activities to increase tourist attraction, improve facilities and infrastructure that can support tourism activities so that tourism development strategies are expected to increase the income of surrounding communities with new jobs, driven by the realization of the role of technology 4.0. These technologies include big data analytics, artificial intelligence, internet of things, robotics, augmented reality, cloud computing, and blockchain. The most concrete example is the robotic airport guide/helper that helps tourists speed up the process of check-in and boarding at the airport

The purpose of this study was to determine the potential natural resources of the Lengkuas Island Nature Tourism Area, Sijuk District, Belitung Regency, Bangka Belitung Islands as a coastal tourism area.

\section{Methodology}

\subsection{Time and Place}

This research was conducted in the area of Lengkuas Island, Sijuk District, Belitung Regency, Bangka Belitung Islands in February - April 2019.

\subsection{Material and Tools}

The research method used is Index of Suitability Tourism Category Recreation and Swimming and Compliance with Boating Category Travel, Canoeing, Banana Boat and Jet Ski. Material and tools used are roller meters, secchidisk, flow parachute, and camera. The determination of stations was carried out based on activities/areas crowded with tourists to do beach recreation tours. The number of stations of this research is 6 points where the coordinates of the location are determined using GPS. (Fig. 1).

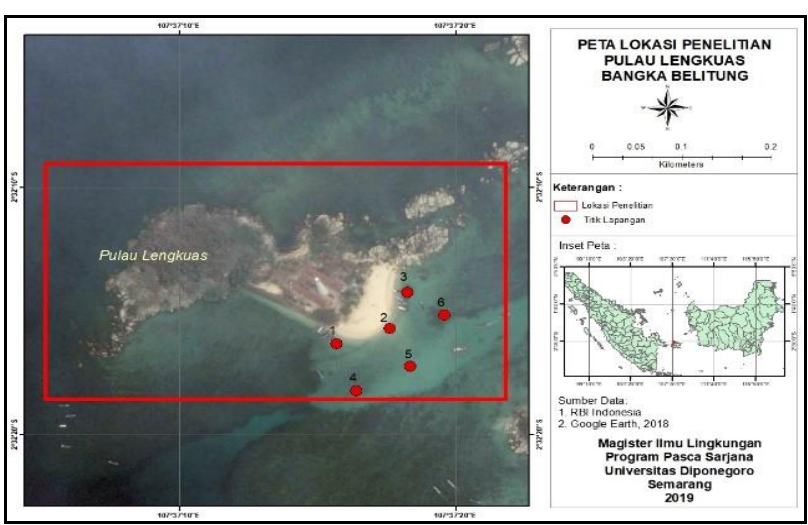

Fig. 1. Map of Research Location

\subsection{Analysis}

\subsubsection{Index of Suitability Tourism Category Recreation and Swimming}

Assessment of the quality of the natural panorama of the coast is used by making observations and direct measurements in the field. This analysis is needed to see whether the area of Lengkuas Island, Belitung Regency meets the standards for coastal tourism. Land suitability criteria are grouped into 3 (three) categories, namely S1 (very appropriate), S2 (accordingly), S3 (not suitable) [4]. Based on the land suitability index value for tourism in table 1. above, the calculation with the highest score is obtained with a value of $100 \%$ and the lowest $<55.56 \%$. Thus, tourism suitability classes can be obtained as follows in Table 1.

Table 1. Index of Suitability Tourism Category Recreation and Swimming

\begin{tabular}{|c|c|c|}
\hline Compliance level & Category & Travel Suitability \\
\hline S1 & Very Suitable & $75-100 \%$ \\
\hline S2 & Accordingly & $50-74 \%$ \\
\hline S3 & Not suitable & $<50 \%$ \\
\hline
\end{tabular}

\subsubsection{Conformity of Boating Category Tourism, Canoeing, Banana Boat and Jet Ski}

Determination of tourist area suitability index based on the calculation of total maximum and minimum values and score intervals. The tourism suitability index is divided into 3 categories, namely S1 (very suitable) with intervals of values 18.7 - 24, S2 (accordingly) 13.3 18.6, S3 (not appropriate) <13.3. Thus, tourism suitability classes can be obtained as follows in Table 2 .

Table 2. Index of Suitability Boating Category Tourism, Canoeing, Banana Boat and Jet Ski

\begin{tabular}{|c|c|c|}
\hline Compliance level & Category & Travel Suitability \\
\hline S1 & Very Suitable & $18.7-24$ \\
\hline S2 & Accordingly & $13.3-18.6$ \\
\hline S3 & Not suitable & $<13.3$ \\
\hline
\end{tabular}




\section{Results and Discussion}

\subsection{Results}

\subsubsection{Index of Suitability Tourism Category Recreation and Swimming}

Stations I, II, and III with a depth of fewer than 5 meters are very feasible for the plan to develop marine tourism in the category of recreation and swimming. Based on Table 3. above research stations I, II, and III have a total score of each other $82(97,6 \%), 79(94 \%)$, and $79(94 \%)$. The tourist suitability matrix in the category of categories is recreation and swimming presented in Table 3.

Table 3. Index of Suitability Tourism Category Recreation and Swimming

\begin{tabular}{|c|c|c|c|c|c|c|}
\hline $\begin{array}{c}\text { Paramet } \\
\text { er }\end{array}$ & $\begin{array}{c}\text { Station } \\
1 \\
\end{array}$ & Score & $\begin{array}{c}\text { Station } \\
\text { II }\end{array}$ & Score & $\begin{array}{c}\text { Statsion } \\
\text { III }\end{array}$ & Score \\
\hline $\begin{array}{l}\text { Depth } \\
\text { (m) }\end{array}$ & 1.75 & 15 & 1.75 & 15 & 1.9 & 15 \\
\hline $\begin{array}{l}\text { Type } \\
\text { beach }\end{array}$ & $\begin{array}{l}\text { White } \\
\text { sand }\end{array}$ & 15 & $\begin{array}{l}\text { White } \\
\text { sand }\end{array}$ & 15 & $\begin{array}{l}\text { White } \\
\text { sand }\end{array}$ & 15 \\
\hline $\begin{array}{l}\text { Wide } \\
\text { beach } \\
(\mathrm{m})\end{array}$ & $37 \mathrm{~m}$ & 15 & $40 \mathrm{~m}$ & 15 & $50 \mathrm{~m}$ & 15 \\
\hline $\begin{array}{l}\text { Water } \\
\text { base } \\
\text { Substrate }\end{array}$ & Sand & 9 & Sand & 9 & Sand & 9 \\
\hline $\begin{array}{l}\text { Flow } \\
\text { speed } \\
(\mathrm{m} / \mathrm{sec}) \\
\end{array}$ & 0.055 & 9 & 0.067 & 9 & 0.067 & 9 \\
\hline $\begin{array}{l}\text { Beach } \\
\text { slope }\end{array}$ & $8^{0}$ & 9 & $11^{0}$ & 6 & $11^{0}$ & 6 \\
\hline $\begin{array}{l}\text { Water } \\
\text { brightnes } \\
\mathrm{s}\end{array}$ & 1.6 & 1 & 1.6 & 1 & 1.7 & 1 \\
\hline $\begin{array}{l}\text { Land } \\
\text { cover }\end{array}$ & $\begin{array}{l}\text { Land } \\
\text { open }\end{array}$ & 3 & $\begin{array}{l}\text { Land } \\
\text { open }\end{array}$ & 3 & $\begin{array}{l}\text { Land } \\
\text { open }\end{array}$ & 3 \\
\hline $\begin{array}{l}\text { Biota } \\
\text { harmful }\end{array}$ & Nothing & 3 & Nothing & 3 & Nothing & 3 \\
\hline $\begin{array}{l}\text { Water } \\
\text { availabili } \\
\text { ty }(\mathrm{m})\end{array}$ & $200 \mathrm{~m}$ & 3 & $350 \mathrm{~m}$ & 3 & $400 \mathrm{~m}$ & 3 \\
\hline \multicolumn{2}{|c|}{ Total } & 82 & & 79 & & 79 \\
\hline \multicolumn{2}{|c|}{$\begin{array}{c}\text { Travel Suitability } \\
(\%)\end{array}$} & 97.6 & & 94 & & 94 \\
\hline \multicolumn{2}{|c|}{ Compliance Level } & S1 & & S1 & & S1 \\
\hline
\end{tabular}

\subsubsection{Index of Suitability Boating Category Tourism, Canoeing, Banana Boat and Jet Ski}

IV, V and VI Stations with a depth of more than 5 meters are very feasible for the plan to develop marine tourism in the category of banana boating, boating, and jet skiing. This is based on measurements of water parameters compared to tourist suitability indexes for the banana boat, boating, and Jet Ski categories. Based on Table 2 above research stations IV, V, and VI each have a total score of 19 . In the boating category of tourist suitability index, the canoe, banana boat, and Jet Ski are included in the very category corresponding. The tourist suitability matrix in the category of categories is a banana boat, boating and jet ski presented in Table 4 .
Table 4. Index of Suitability Boating Category Tourism, Canoeing, Banana Boat and Jet Ski.

\begin{tabular}{|l|c|c|c|c|c|c|}
\hline Parameter & $\begin{array}{c}\text { Station } \\
\text { IV }\end{array}$ & Score & $\begin{array}{c}\text { Station } \\
\text { V }\end{array}$ & Score & $\begin{array}{c}\text { Station } \\
\text { VI }\end{array}$ & Score \\
\hline Depth (m) & $>4-8$ & 10 & $>4-8$ & 10 & $>4-8$ & 10 \\
\hline $\begin{array}{l}\text { Flow speed } \\
(\mathrm{m} / \mathrm{sec})\end{array}$ & $0-0,15$ & 9 & $0-0,15$ & 9 & $0-0,15$ & 9 \\
\hline \multicolumn{2}{|c|}{ Total } & 19 & & 19 & & 19 \\
\hline
\end{tabular}

\subsection{Discussion}

The result of suitability analysis for beach and swimming recreation activities is located at Station I, II, and III. The area analyzed is the area that is usually used by tourist visitors as a place to do many activities in the area. The station is considered suitable as a swimming area because the depth does not reach 3-4 meters. Visitors usually swim at a depth of no more than 2 meters to anticipate security and safety in swimming or other recreational activities.

The depth of the Lengkuas Island beach for recreational activities and swimming is an average of 2 meters deep in water. This depth is one of the mandatory factors that visitors/tourists pay attention to for recreational activities and swimming. This activity is not only carried out by adult visitors. Based on the results of observations in the field there are several children who do swimming activities. In this area, there is also no officer in the security of swimming tours that will oversee visitor activity in the water column. In the coastal tourism suitability matrix, the depth of $0-3 \mathrm{~m}$ is the most suitable. In this case, the researcher concludes that the depth of the waters of Lengkuas Island is very safe for coastal ecotourism activities in the recreation category especially bathing and swimming. This is in accordance with the opinion of [5] suggesting that swimming activities, the best depth is in the range 0-3 m. Other factors related to the prevention of drowning are having security and safety monitoring posts on the shoreline. Based on the results of measurements that have been made in the field, it shows that based on the depth at stations 1, 2 and 3, Lengkuas Island is very suitable as a beach recreation and swimming tour.

The beach type on Lengkuas Island Beach is a white sand beach. The type of sandy beach is more suitable for tourism activities than for muddy or rocky beaches. The beach width reaches $>15 \mathrm{~m}$.

The width of the coast of Lengkuas Island is $>15$ meters with slightly sloping terrain and can be used by visitors/tourists for activities such as walking leisurely, taking pictures, and sunbathing. From these components based on this study, it is very suitable to be used as a tourist activity in the recreation and swimming category. The beach width $>25$ meters with sloping terrain and not narrow can be used by visitors to walk leisurely, sunbathe, and so on [6]. Based on the research that has been done the type and width of the beach of Lengkuas Island is suitable for tourism activities in the recreation and swimming category.

The basic water/material base substrate in the waters of Lengkuas Island is white sand. The white sand base substrate is very suitable for recreational and swimming 
tourism activities. In the tourism suitability matrix for recreation and swimming categories [4] that the most ideal white sand material base (highest weight) in supporting these activities. This is made clear by the statement of [7] that the coast always experiences a lowwave climate and weak currents, the location of the coast close to an industry can affect the bottom of the water substrate. Black sand reduces aesthetics and can trigger psychological concerns for tourists who come to visit. Good beach sand consists of shell fragments and quartz with magnetite, manganese and white elements.

The current velocity on the beach of Lengkuas Island in this study ranged from $0.055 \mathrm{~m} / \mathrm{s}$ to $0.067 \mathrm{~m} / \mathrm{s}$. The current speed range is very feasible for swimming beach tourism activities. In accordance with the opinion of [8] factors that have a major impact on open water security such as weather, waves, waves, velocity of currents, tides, river currents, and wind are things that must be considered in recreational areas, these conditions can increases the risk of drowning with the effects of hypothermia and respiratory failure. Current velocity is included in the components of coastal tourism suitability. Waters with fast currents are not suitable for swimming, which can endanger the safety of tourists. In the tourist suitability matrix [4] the current velocity that best fits the swimming recreation category is in the range $0-0.2 \mathrm{~m} / \mathrm{s}$.

The slope of the beach will affect safety and comfort in tourism, especially swimming. The slope of the beach can also experience a change, changes due to the height of the water can cause large changes in the width of the beach [9]. Based on its slope, [4] suggests that the type of beach in general is divided into 4 types namely flat beach, steep and steep slope. Turkish flat has a flatter slope slop $<10^{\circ}$, ramps $10^{0}-25^{\circ}$ and steep $>45^{\circ}$. Lengkuas Island beach has a gentle beach type. Sloping beaches can generally be used for a variety of beach tourism recreational activities, both small and adult children.

In the tourism leisure suit matrix the beach category and swim the most appropriate brightness value is $>10$ $\mathrm{m}$. The average brightness in this study ranged from $5 \mathrm{~m}$. The brightness value is relatively low when compared to the travel suitability matrix. This condition is caused by the weather and the temperature that affects when sampling, where the intensity of sunlight is not optimal and the basic substrate that had risen to the surface of the sea due to rain [10]. The brightness of the waters in relation to coastal ecotourism activities plays an important role in terms of the comfort of tourists when swimming.

Land closure in the tourism suitability category for recreation and swimming matrices is divided into open land and coconut, low shrubs and high shrubs, settlements and ports. Land closure on the coast of Lengkuas Island is open land. Open type of land cover is very suitable for beach tourism activities. [11] suggested a large portion of small island vegetation based on the size and height of trees on the location, the beach which has a large portion of old coconut trees and is formed by extensive sandy coastal areas that are very good for turtle nesting areas and tourist categories, especially for tourists.
Hazardous biotas are not found in the Lengkuas Island Beach area so this area is safe to support swimming activities. Retrieval of data regarding the presence of dangerous biota in the waters by digging indepth information to visitors, surrounding communities and managers. Thetmeyer [12] suggested biotas such as sea urchins, small sharks, and jellyfish as several biotas that must be wary of when carrying out water activities because attacks from these biotas can endanger humans if they do not know how to cope/cure them. The existence of the diversity of biota, especially dangerous biota will endanger the tourists who swim and snorkel. Based on direct observations in the field by snorkeling at the three predetermined stations, no dangerous biota on Lengkuas Island can be concluded that according to [4] is in the very appropriate category (S1) for Suitability of Areas for Recreational Coast Tourism. However, based on the results of interviews with the guards who live around the recreational tourism area, they said that the presence of dangerous biota on Lengkuas Island was seasonal, such as sea urchins.

On the beach of Lengkuas Island, there is one lighthouse that is useful for guiding fishing boats at night and 2 places/buildings to just rinse. Access to these locations is quite easy. Based on the results of the research in the field the distance between Freshwater Availability is station 1 and $2(<500 \mathrm{~m})$ station $3(400$ $\mathrm{m})$. This is if seen according to the Regional Suitability Matrix for [4] Distance of Freshwater Availability between the location of the tourist area is very suitable (S1) which is $<0.5 \mathrm{~km}$. When conducting tourism activities, the availability of clean water in the form of freshwater is needed to support management facilities and tourism services. Rainwater harvesting is a technique used for collecting, storing and using rainwater for domestic, agricultural or any other uses [13]. The rainwater is collected from various hard surfaces such as rooftops, runoff from catchments, from streams and water conservation through watershed management or other manmade aboveground hard surfaces.

From the assessment of all tourism suitability parameters, station I has a total IKW value of $97 \%$, station II has an IKW value of $94 \%$ and has an IKW value of $94 \%$. Based on the tourism suitability index in general, all locations in this study which are located in the Lengkuas Island Beach area are very suitable for beach tourism, recreation, and swimming categories.

\section{Conclusion}

Based on the results of the study show generally that the suitability of Lengkuas Island beach tourism is suitable for marine tourism activities. Based on the results of tourism suitability analysis, the area of Lengkuas Island is very suitable for beach recreation and swimming activities (Stations I, II, and III). In the planned development of tourist areas Stations IV, V, and VI are very suitable for tourism activities in the category of boating, canoeing, banana boating, and jet water skiing. Tourism era 4.0 is an adaptation of digitalization that 
happened because it affected the 4.0 industrial revolution. The world tourism sector, including Indonesia, responds to this as a digital change in ecosystems.

Among them are forming a millennial community to find out through digital media and develop digital destinations, where destinations are conceptualized by finding the current destination, one of them is Lengkuas Island. This effort has been carried out systematically to reach the millennial tourist market as the future tourist.

\section{References}

1. G.D. Alperstedt, S. Bulgacov, Environmental management, strategic practices and praxis: A study in Santa Catarina industrial companies, BAR - Brazilian Administration Review 12(3), 288-308 (2015)

2. D. Dredge, G. Phi, R. Mahadevan, E. Meehan, E.S. Popescu, Digilisation in Tourism In-Depth Analysis of Challenges and Opportunities, Low Value procedure GRO-SME-17-C-091-A for Executive Agency for Small and Medium-sized Enterprises (EASME) Virtual Tourism Observatory. Aalborg University, Copenhagen (2018)

3. H. Husin, H. Kartono, Potential Maritime Tourism Areas in Belitung Regency (Thesis), Master Program of Geography - University of Indonesia (2011)

4. F. Yulianda, Marine Ecotourism as an Alternative to the Use of Coastal Resources Based on Conservation, Standar Sains Department of Aquatic Resources Management Faculty of Fisheries and Marine Science - Bogor Agricultural Institute (2007)

5. K. Moran, R.K. Stallman, P.L. Kjendlie, D. Dahl, J.D. Blitvich, L.A. Petrass, S. Shimongata, Can
You Swim? An Exploration of Measuring Real and Perceived Water Competency, International Journal of Aquatic Research and Education 6(2), 122-135 (2012)

6. A.R. Quicoy, N.D. Briones, Beach Carrying Capacity Assessment of Coastal Ecotourism in Calatagan, Batangas, Phlippines, Journal of Environmental Science and Management 12(2), 11-26 (2009)

7. P. Chandramohan, V.S. Kumar, Fine Particle Deposition at Vainguinim Tourist Beach, Goa, India, Journal of Coastal Research 1074-1 081. Royal Palm Beach. Florida susu, 1-8 (2008)

8. K. Moran, L. Quan, R. Franklin, E. Bennett, Where the Evidence and Expert Opinion Meet: A Review of Open-Water Recreational Safety Messages, International Journal of Aquatic Research and Education 5(3) (2017)

9. S. Hammann, M. Zimmer, Wind-Driven Dynamics of Beach-Cast Wrack in a Tide-Free System, Open Journal of Marine Science 04(02), 68-79 (2014)

10. R. Anita, Faisal, H. Meilina, The Quality and Distribution of Water at Krueng Geukueh Waters in North Aceh Regency - Indonesia, International Journal of Academic Research in Environment and Geopgraphy 5(1), 83-99 (2018)

11. E. Saleh, T. Aung, Changes in Small Islands of Tourist Destination. Journal for Sustainable Development 1(1), 21-33 (2013)

12. H. Thetmeyer, U. Kils, To see and not be seen: the visibility of predator and prey with respect to feeding behaviour, Marine Ecology Progress Series 126(1-3), 1-8 (1995)

13. S. Ward, F.A, Memon, D. Butler, Rainwater Harvesting: Model-Based Design Evaluation, Proceedings of the $11^{\text {th }}$ International Conference on Urban Drainage, Edinburgh. Scotland, UK (2008) 